Original article

\title{
Impact of change in household hygiene conditions on morbidity in India: Evidence from longitudinal survey
}

\author{
N. Brahmanandam *, R. Nagarajan \\ Department of Development Studies, International Institute for Population Sciences (IIPS), Govandi Station Road, Deonar,Mumbai, 400088, Maharashtra, India
}

\section{A R T I C L E I N F O}

\section{Keywords:}

Any short term morbidity

Household hygiene conditions

India Human development survey

Longitudinal data and India

\begin{abstract}
A B S T R A C T
The maintenance of good hygiene is more important to prevent communicable and infectious diseases. Therefore, the main aim of this study to assess the impact of change in household hygiene conditions on morbidity. The results from multivariate linear regression have shown that the percentage share of households members fell sick due to any short term morbidity were significantly higher $(\beta=0.053, \mathrm{P}<0.001)$ among the households who had lived in the poor hygiene conditions in both years in 2005 and 2011 compared to the households who were lived in the better-off hygienic condition in both years in 2005 and 2011 after controlling various socio-economic variables. The household members who fell sick due to any short term morbidity had significantly declined $(\beta=-0.028, \mathrm{P}<0.04)$ among the households who were lived in the poor condition in 2005 , but transformed into better off hygienic condition as a compared to the households who were lived in the poor hygienic condition in both years in 2005 and 2011. Similarly, the results from multinomial logistic regression shown that prevalence of any short term morbidity was significantly less likely among the households who were livid remain in the better-off hygienic condition in both years in 2005 and $2011(2.8 \%$; $<0.01)$ as compared to other households who were lived remain in the poor hygiene conditions in 2005 and 2011 (4.8\%). Findings of this study suggest that not only improve the water and sanitation facilities which are prerequisites for hygiene but also improve the hygienic behavior of the households through social media.
\end{abstract}

\section{Introduction}

Hygiene is defined as conditions and practices that help prevent the spread of the disease and promote better health and well-being of the population. ${ }^{1}$ Hygienic practices include frequent handwashing, face washing, washing clothes, food hygiene, and water purifying and bathing with soap. ${ }^{2}$ The previous studies have been suggested that better hygienic practices through handwashing with soap, food protection, and domestic hygiene brought a reduction in infant diarrhea by $33 \% .^{3,4}$, Practicing hygiene is difficult without clean water and sanitation. The lack of clean water and improved sanitation facilities, poor hygienic practices, the low hygienic status of shared sanitation facilities, fecal contamination in water, as well as inadequate handwashing practices causes diarrhea among children below five years in developing countries. ${ }^{3-5}$ Handwashing with soap (HWWS) has a significant effect on health and reduced diarrhea. Several studies were found that a one-third reduction of diarrhea episodes among the children after community intervention of hygienic practices in low and middle-income countries. $^{6-9}$
Diarrhoeal diseases are among the leading causes of morbidity and mortality in young children in developing countries. ${ }^{11}$ Each year, an estimated 2.5 billion cases of diarrhea occur among children under five years of age. Africa and Asia account for over half the cases of childhood diarrhea, ranked as the fourth leading cause of mortality among under-five children. ${ }^{12}$ It was found that $1 \mathrm{~g}$ of diarrhea contained $10^{12}$ viruses and 10 million bacteria though all are not pathogenic. ${ }^{10}$

Hygiene practices are vital to one's health and well-being, especially in the prevention of communicable and infectious diseases. Water supply, hygiene, and sanitation are highly demanding to lower and avoid the burden of communicable diseases significantly. ${ }^{13}$ Especially hand hygiene is considered one of the most important infection control measures since it breaks the transmission of microorganisms, especially in medical centers. ${ }^{14,15}$ Improved hand washing of mothers and children prevents diarrhea diseases and other infectious diseases among the children, which turned to reduce stunting among the children below five years. $^{16}$

Even though the availability of water and sanitation facilities, unless people are knowledgeable on the health risk posed for not practicing

\footnotetext{
* Corresponding author.

E-mail addresses: brahmameco@gmail.com (N. Brahmanandam), nagarajan@iipsindia.ac.in (R. Nagarajan).
} 
proper hygiene, it is likely that they ignore or under practice hygiene. ${ }^{17}$ Therefore, Providing improved water supply and sanitation facilities alone do not lead to automatically adopt their hygienic practices ${ }^{2}$ and Proper hygiene cannot be ensured with the only provision of hygiene facilities. ${ }^{18}$ Even though sanitation and hygiene facilities are available, the users' behavior does matter in the effective control of those communicable diseases. People could practice hygiene simply because they are used to or might have just inherited the practice from their parents or colleagues. ${ }^{19,20}$ Therefore it is necessary to make them aware of good hygienic practices through social media then it can reduce the morbidity. Besides, it should be noted that washing hands with or without soap and doing it the right way matters. It was found that Children who were undernourished owing to low socioeconomic category and not who having good hygienic practices more likely to get diseases. ${ }^{21}$ Due to repeated illness, children miss' classes, and therefore they may not perform well in the examination. ${ }^{22}$ The possible reasons for poor hygiene among adolescent children are lack of awareness about good personal hygiene among the parents. ${ }^{22}$ Therefore, it is necessary to make awareness about the knowledge and practices of hygiene. For instance, implementing traditional and modern communication programs about the hygienic condition to reach out to mothers and children succeeded in improving hygiene among Western Africa's targeted population. For instance, handwashing with soap observed after cleaning a child's bottom rose from $13 \%$ to $31 \% .^{10}$

In India, the previous cross-sectional studies have been attempted to effect of hygienic conditions as only handwashing behavior with soap or without soup after defecation on diarrhea morbidity among the children. ${ }^{4,10}$ However, all these studies are cross-sectional, which does not show the impact or causation. Therefore taking this literature gap, this study makes two contributions. 1). To assess the average percentage share of household members fall sick due to any short-term morbidity with respect to change in household hygiene conditions in different socio-economic characteristics of the households .2). To assess the impact of change in hygiene conditions on morbidity members of the households.

\section{Materials and methods}

\subsection{Data}

The present study uses data of two rounds of a longitudinal survey of India Human Development Survey 2004-05 and 2011-12. It is a nationally representative survey carried out in collaboration with the researchers at the University of Maryland and the National Council of Applied Economic Research (NCAER), New Delhi. The First (IHDS-I 2004-05) wave of the survey was administered to a nationally representative sample of 41,554 households. IHDS-II (2011-12) reinterviewed $83 \%$ of households from IHDS-I, with the additional replacement of a sample of 2134 households. ${ }^{23}$ The total sample size of IHDS-II was 42,152 households. Both surveys have collected household information on income, education, health, consumption expenditure, fertility, and family planning. These surveys also collected information on household hygiene conditions and any short term morbidity of all members. Both surveys covered all the states and union territories of India except Andaman/Nicobar and Lakshadweep Islands. For analytical purposes in this study, we used sample size of 34,131 households in 2011-12 which has been followed up from base period of 2004-05 after attrition of 6, 911 households.

\subsection{Sample design}

The IHDS is a nationally representative survey of 41,554 urban and rural households in 2004-05. These households are spread across 33 states and union territories, 384 districts, 1503 villages, and 971 urban blocks, located in 276 towns and cities. Villages and urban blocks (comprising of 150-200 households) formed the primary sampling unit
(PSU) from which the households were selected. Urban and rural PSUs were selected using different design. To draw a random sample of urban households, all urban areas in a state were listed in the order of their size with the number of blocks drawn from each urban area allocated based on probability proportional to size. Once the numbers of blocks for each urban area were determined, the enumeration blocks were selected randomly with help from office of the Registrar General of India. From these Census Enumeration Blocks of about 150-200 households, a complete household listing was conducted and household samples of 15 households per block were selected. ${ }^{24}$

\subsection{Variables}

They are two outcome variables in this study. The first outcome variable is the linear variable: the percentage of household members fall sick due to any short term morbidity (Diarrhea, Fever, and Cough) is continuous. The second outcome variable is multinomial variable comprising four categories indicating transition nature of short-term morbidity among the household members: (a) the percentage of household members fall sick due to any short term morbidity (hereafter ASM) remains the same in 2005 and 2011; (b) the percentage of household members fall sick due to ASM in 2005 but is not sick in 2011.3) the percentage of household members who were not sick in 2005 but fell sick due to any ASM in 2012; (d) the percentage of household members remain without ASM in 2005 and 2011.

The main predictor variable in this study change in household hygiene conditions. It is classified into four categories to reflect transition pattern: (a) Remaining poor hygiene in 2005 and 2011; (b) Poor hygiene in 2005 and non-poor hygiene in 2011; (3) Non-poor hygiene in 2005 and became poor hygiene in 2011; (4) Remain non-poor hygiene in 2005 and 2011. The controlled variables are different demographic and socioeconomic variables such as Place of residence (rural and urban), type of house (Kucha [made with mud] and pucca [ improved house as it made with bricks and cement]), economic status (poor and non-poor), occupational status (primary, secondary, tertiary, and no-occupation), educational level of head of the household (illiterate, primary, secondary and higher), social group categories (General, Other Backward Caste, Scheduled Caste and Scheduled Tribe), religious group (Hindu, Muslim and Other [Christian, Sick, Jain, Buddhist, tribal, others and non-]), and regions (Northern, Central, Eastern, Northeast, Western and Southern). The descriptive statistics of all these variable and sample size for round- 1 and round -2 of IHDS are described in Table 1.

\subsection{Analysis}

By using the information on household hygienic behavior, 7 variables were dichotomized as 0 for disadvantaged and 1 for the advantaged group (Table 2) and then the estimation of the household hygienic condition index based on 7 household hygienic condition variables from panel household data of two periods of time for 2004-05 and 2011-12. The household hygienic index was constructed by using Principal Component Analysis, based on household data. Each of the household hygiene condition variable, weight (factor score) is generated from the PCA was assigned. The result of household hygienic condition scores was standardized in relation to normal distribution with zero mean and standard deviation one, then values divided into three equal parts as Poor, middle and better off condition of households for two periods of household data. The estimation of household hygienic condition Index was adopted from DHS methodology. ${ }^{38,39}$ the reliability, validity, and suitability of seven components used in the Index were carefully examined both quantitatively and theoretically. The reliability coefficients are reported at the bottom in Table 2. As a pointed out above, the Index was classified into four categories to represent transition pattern: (1) Remaining poor hygiene in 2005 and 2011; (2) Poor hygiene in 2005 and non-poor hygiene in 2011; (3) Non-poor hygiene in 2005 and became poor hygiene in 2011; (4) Remain non-poor hygiene in 2005 
Table 1

Description of the percentage and sample distribution of the study variables, Indian Human Development Survey, 2004-05 and 2011-12.

\begin{tabular}{|c|c|c|c|c|}
\hline & $2004-05 \%$ & $\mathrm{~N}$ & $2011-12 \%$ & $\mathrm{~N}$ \\
\hline \multicolumn{5}{|l|}{ Place of residence } \\
\hline Rural & 75.4 & 23,642 & 72.5 & 22,841 \\
\hline Urban & 24.6 & 10,489 & 27.5 & 11,290 \\
\hline \multicolumn{5}{|c|}{ Chi-square test $43.2625, \mathrm{P}<0.000$} \\
\hline \multicolumn{5}{|l|}{ Type of House } \\
\hline Kucha & 67.71 & 21,505 & 59.7 & 18,820 \\
\hline Pucca & 32.29 & 12,626 & 40.3 & 15,311 \\
\hline \multicolumn{5}{|c|}{ Chi-square test $55.0118, \mathrm{P}<0.002$} \\
\hline \multicolumn{5}{|l|}{ Occupation } \\
\hline Primary & 66.1 & 21,829 & 64.7 & 21,270 \\
\hline Secondary & 9.6 & 3292 & 18.8 & 6466 \\
\hline Tertiary & 16.6 & 6166 & 15.4 & 6017 \\
\hline No-Occupatiion & 7.7 & 2844 & 1.0 & 378 \\
\hline \multicolumn{5}{|c|}{ Chi-square test $66.0121, \mathrm{P}<0.002$} \\
\hline \multicolumn{5}{|l|}{ Education } \\
\hline Illiterate & 63.9 & 21,541 & 62.2 & 21,100 \\
\hline Primary & 13.0 & 4331 & 11.9 & 4004 \\
\hline Secondary & 20.4 & 7194 & 22.3 & 7737 \\
\hline Higher & 2.8 & 1065 & 3.6 & 1290 \\
\hline \multicolumn{5}{|c|}{ Chi-square test $58.6341, \mathrm{P}<0.0001$} \\
\hline \multicolumn{5}{|l|}{ Economic status } \\
\hline Poor & 22.1 & 7154 & 18.4 & 5768 \\
\hline Non-poor & 77.9 & 26,977 & 81.6 & 28,363 \\
\hline \multicolumn{5}{|c|}{ Chi-square test $183.3735, \mathrm{P}<0.0001$} \\
\hline \multicolumn{5}{|c|}{ Caste } \\
\hline General & 28.0 & 10,546 & 25.9 & 9732 \\
\hline OBC & 41.5 & 13,564 & 41.8 & 13,713 \\
\hline SC & 22.8 & 7157 & 22.7 & 7192 \\
\hline ST & 7.8 & 2864 & 8.0 & 2961 \\
\hline \multicolumn{5}{|l|}{ Chi-square test $6.3088, \mathrm{P}<0.008$} \\
\hline \multicolumn{5}{|l|}{ Religion } \\
\hline Hindu & 83.0 & 27,736 & 83.2 & 27,942 \\
\hline Muslim & 11.0 & 3822 & 11.1 & 3850 \\
\hline Christian & 6.0 & 2573 & 2.4 & 1059 \\
\hline Others & & & 3.3 & 1280 \\
\hline \multicolumn{5}{|l|}{ Chi-square test $12.0118, \mathrm{P}<0.002$} \\
\hline \multicolumn{5}{|l|}{ Region } \\
\hline North & 13.4 & - & - & 7624 \\
\hline Central & 21.5 & - & - & 6584 \\
\hline East & 22.9 & - & - & 5807 \\
\hline Northeast & 3.1 & - & - & 1422 \\
\hline West & 15.6 & - & - & 4683 \\
\hline South & 23.5 & - & - & 8011 \\
\hline \multicolumn{5}{|c|}{ NA } \\
\hline \multicolumn{5}{|c|}{ Change in household hygiene condition } \\
\hline Poor in $2005 \& 2011$ & 28.9 & - & - & 7772 \\
\hline Poor in 2005 but Non-poor 2011 & 23.4 & - & - & 7161 \\
\hline Non-poor 2005 but Poor 2011 & 11.5 & - & - & 4132 \\
\hline Non-poor in $2005 \& 2011$ & 36.2 & - & - & 15,066 \\
\hline \multicolumn{5}{|l|}{ NA } \\
\hline Change in any short term morb & & & & \\
\hline No-sick $2005 \& 2011$ & 73.2 & - & - & 24,993 \\
\hline No-sick 2005\& sick 2011 & 13.8 & - & - & 4710 \\
\hline Sick 2005\& no-sick 2011 & 9.74 & - & - & 3326 \\
\hline Sick 2005\&2011 & 3.2 & - & - & 1102 \\
\hline Chi-square test & & & & \\
\hline Mean percent ASM & 11.9 & 34,131 & 18.1 & 34,131 \\
\hline
\end{tabular}

Note: NA stand for not applicable to adopt the Chi-squire test because only one individual variable is available for both survey periods therefore it is not possible test association of variation for single variable; $\mathbf{N}$ stands for sample size.

and 2011.

The analyses were carried out in two stages. In the First stage, we modeled bivariate analysis and an ANOVA test to estimate significant difference in the average percentage of household members fall sick due to any short term morbidity by the change in household hygienic condition across the various socio-economic characteristics of households. In the second stage, we modeled two sets of analyses based on the nature of the dependent variables. First, for the continuous dependent variable, we have used multivariate linear regression to assess the impact of change in household hygienic conditions on the percentage of members
Table 2

Indicators included in Household Hygienic Condition index.

1. Households having vessel with lid for drinking water storage are considered hygienic (1), while no vessel for storage and vessels with no lid are unhygienic (0)

2. The households always purify the drinking water have better hygienic conditions (1) than those which never, rarely, sometimes and usually purify (0).

3. Improved methods of pouring drinking water are using long ladle and tap in the vessels (1), while the unimproved methods include cups and utensils (0)

4. The members of the households practicing hand wash after defecation is grouped as hygienic practices (1) and it is unhygienic on the other way (0).

5. Members of the households wash hands using soap after defecation are grouped into hygienic practice (1), while the hand wash using other material such as water alone, mud/ash and others are unhygienic practices $(0)$.

6. The households with separate kitchen are categorized as having improved cooking place (1), and unimproved conditions include cooking in outdoors and in living area such as un hygiene place (0)

[Reliability coefficients: Estimated Household Environment Condition Index's Alpha coefficient in 2004-05 is 0.63 and in 2011-12 is 0.65 which shows reliable and consistency of 6 variable used in Index].

of households fall sick due to any short term morbidity. Second, we applied the multinomial logistic regression and Multiple Classification Analysis (MCA) conversion to see the impact of change in household hygiene conditions in response to change in morbidity members of households. Because the dependent variable change in morbidity members of households classified as four categories as pointed out above in the variable section. The results of regression coefficients were converted into adjusted percentage terms for the sake of convenience in interpretation. $^{25}$

The mathematical equation of MCA multinomial analysis is as follows:

$Z_{1}=\log \left(\frac{P_{1}}{P_{4}}\right)=a_{1}+\sum b_{1 j} * X_{j}$

$Z_{2}=\log \left(\frac{P_{2}}{P_{4}}\right)=a_{2}+\sum b_{2 j} * X_{j}$

$Z_{3}=\log \left(\frac{P_{3}}{P_{4}}\right)=a_{3}+\sum b_{3 j} * X_{j}$

And. $P_{1}+P_{2}+P_{3}+P_{4}=1$

Where,

ai $\mathrm{i}=1,2$ : constants

bij $\mathrm{i}=1,2 ; \mathrm{j}=1,2 \ldots \mathrm{n}$ : multinomial regression coefficient.

$P_{1}=$ Estimated probability of household members fell sick due to ASM remained the same in 2005 and 2011.

$P_{2}=$ Estimated probability of household members not sick due to ASM in 2005 but fell sick due to ASM in 2011.

$P_{3}=$ Estimated probability of household members fell sick due to ASM in 2005 but not sick due to ASM in 2011.

$P_{4}=$ Estimated probability of household members remained not sick due to ASM in 2005 and 2011.

Hear $\mathrm{P}_{4}$ is a reference category

For the sake of simplicity in the interpretation of results, multinomial logistic regression coefficients were converted into adjusted percentages. The procedure consists of following steps:

Step 1:

By using regression coefficient and mean values of independent variables, the probability was computed as:

$$
P_{i}=\frac{\exp \left(Z_{i}\right)}{\left\{1+\sum \exp \left(Z_{i}\right)\right\}}, \mathrm{i}=1,2,3,4 \text { and } P_{4}=1-P_{1}+P_{2}+P_{3} \text { where } \mathrm{Z} \text { was }
$$
the estimated value of response for all categories of each variable. 
Step 2:

To obtain the percentage values, the probability $\mathrm{P}$ was multiplied by 100.

All the analyses for this paper were carried out by using STATA 13.1 version.

\section{Results}

\subsection{The change in household hygiene conditions and ASM in different socioeconomic characteristics}

Table 3 shows that the average percentage of household members fell sick due to any short term morbidity (Diarrhea, fever, and cough) by the change in household hygiene conditions with various demographic and socio-economic characteristics in India.

The results shown that average members of household members fell

Table 3

Average percentage members of households fall in sick due to short term morbidity according to change in their household hygienic behavior and socioeconomic characteristics.

\begin{tabular}{|c|c|c|c|c|c|}
\hline \multirow[t]{2}{*}{$\begin{array}{l}\text { Background } \\
\text { variables }\end{array}$} & \multicolumn{4}{|c|}{$\begin{array}{l}\text { Average percentage of household members } \\
\text { with short term morbidity by change of the } \\
\text { household hygienic behavior }\end{array}$} & \multirow[b]{2}{*}{$\begin{array}{l}\text { Anova test } \\
\text { value and } \\
\text { significance } \\
\text { level }\end{array}$} \\
\hline & $\begin{array}{l}\text { Poor in } \\
2005 \& \\
2011\end{array}$ & $\begin{array}{l}\text { Poor in } \\
2005 \text { but } \\
\text { Non- } \\
\text { poor in } \\
2011\end{array}$ & $\begin{array}{l}\text { Non- } \\
\text { poor in } \\
2005 \text { but } \\
\text { Poor in } \\
2011\end{array}$ & $\begin{array}{l}\text { Non- } \\
\text { poor in } \\
2005 \& \\
2011\end{array}$ & \\
\hline \multicolumn{6}{|l|}{$\begin{array}{l}\text { Place of } \\
\text { residence }\end{array}$} \\
\hline Rural & 21.9 & 18.3 & 19.3 & 17.6 & $16.93^{* * *}$ \\
\hline Urban & 15.3 & 13.4 & 15.1 & 13.5 & \\
\hline \multicolumn{6}{|l|}{ Type of house } \\
\hline Kucha & 22.2 & 18.5 & 19.6 & 17.0 & $15.67 * * *$ \\
\hline Pucca & 16.1 & 13.9 & 15.7 & 14.7 & \\
\hline \multicolumn{6}{|l|}{$\begin{array}{l}\text { Occupation } \\
\text { head of the } \\
\text { Household }\end{array}$} \\
\hline Primary & 21.8 & 18.2 & 19.0 & 16.0 & $10.62 * * *$ \\
\hline Secondary & 17.9 & 15.4 & 17.0 & 17.2 & \\
\hline Tertiary & 20.0 & 15.0 & 17.7 & 14.7 & \\
\hline No Occupatiion & 21.7 & 15.7 & 18.2 & 16.3 & \\
\hline \multicolumn{6}{|l|}{$\begin{array}{l}\text { Household } \\
\text { head's } \\
\text { education }\end{array}$} \\
\hline Illiterate & 21.6 & 18.2 & 19.5 & 16.6 & $10.62^{* * *}$ \\
\hline Primary & 18.8 & 16.0 & 18.0 & 15.9 & \\
\hline Secondory & 21.4 & 15.2 & 16.3 & 14.6 & \\
\hline Higher & 21.4 & 15.4 & 15.2 & 15.0 & \\
\hline \multicolumn{6}{|l|}{$\begin{array}{c}\text { Economic } \\
\text { Status }\end{array}$} \\
\hline Poor & 20.3 & 17.5 & 23.3 & 18.9 & $26.15^{* * *}$ \\
\hline Non Poor & 21.8 & 17.3 & 17.0 & 15.2 & \\
\hline \multicolumn{6}{|l|}{ Caste Group } \\
\hline General & 21.9 & 16.8 & 18.1 & 14.9 & $12.35^{* * *}$ \\
\hline OBC & 22.9 & 17.4 & 19.8 & 16.3 & \\
\hline SC & 20.7 & 18.8 & 20.4 & 18.3 & \\
\hline ST & 15.0 & 14.3 & 12.5 & 11.6 & \\
\hline \multicolumn{6}{|l|}{ Religion } \\
\hline Hindu & 21.3 & 17.4 & 19.3 & 16.0 & $22.34^{* * *}$ \\
\hline Muslim & 23.3 & 17.4 & 19.1 & 14.8 & \\
\hline Christian & 14.1 & 15.9 & 8.5 & 15.2 & \\
\hline \multicolumn{6}{|l|}{$\begin{array}{l}\text { Regions in } \\
\text { India }\end{array}$} \\
\hline North & 18.7 & 15.3 & 18.4 & 17.9 & $29.03 * * *$ \\
\hline Central & 27.7 & 28.4 & 29.4 & 23.8 & \\
\hline East & 21.6 & 17.3 & 15.3 & 16.8 & \\
\hline Northeast & 9.7 & 11.9 & 12.3 & 10.0 & \\
\hline West & 15.2 & 12.7 & 14.7 & 10.2 & \\
\hline South & 16.4 & 14.8 & 12.2 & 13.4 & \\
\hline Total & 21.3 & 17.4 & 18.6 & 15.8 & \\
\hline
\end{tabular}

sick due to ASM was significantly higher (21.3\%) among the household who's hygiene conditions remained poor in both years in 2005 and 2011 in India as compared to non-poor hygiene conditions of the households (15.8\%) in both years in 2005 and 2011. The morbidity has been declined (17.4\%) in the households whose hygiene conditions have been changed into better-off in the recent year in 2011 from the poor hygiene condition in 2005. Whereas, the morbidity has been increased (18.6\%) among the households whose hygiene conditions have been changed into worse-off in 2011 from better-off in 2005. It clearly states that the households were continuously living with better-off hygiene practices not only reduce the morbidity but also keep healthier.

With respect to the place of residence (rural vs urban) of households, among the household members who have lived in worse-off hygiene conditions in 2005 and 2011, the morbidity of rural and urban household members was higher ( $21.9 \%$ and $15.3 \%$ respectively) as compared with the rural (17.6\%) and urban households (13.5\%) who have lived in better-off hygiene conditions in both years in 2005 and 2011. Among the rural and urban households who were turned from worse-off hygiene conditions in 2005 to better-off conditions in 2011, their morbidity of household members were declined by $18.3 \%$ and $13.4 \%$ respectively. Whereas the morbidity members of the rural (19.3\%) and urban $(15.1 \%)$ households were increased when their hygiene conditions have been changed into worse off in 2011 from better-off conditions in 2005. It has been observed that even among the rural and urban households who have continued living in better-off hygiene condition has shown less morbidity compared to those household living in worse-off hygiene condition irrespective place of residence.

A similar pattern of results evident across all other socioeconomic characteristics of the households. The results of the ANOVA test has shown significance change in average percentage members of households fall sick due to morbidity across the all socioeconomic characteristic of the households with respect to the transition of household hygiene conditions.

\subsection{The transition in household hygiene conditions and its relation to ASM across the major states in India}

Table 4 indicates that the average percentage of household members fall sick due to any short-term morbidity is shown across the all the major states with respect to change in household hygiene conditions in India. The results indicate that morbidity of household members across the all states have shown increased when their hygienic condition of households has been turned into the poor hygienic condition in 2011 from non-poor in 2005. Whereas, the morbidity of all major states have shown declined, when their household hygiene conditions have been turned into better off condition in 2011 from poor conditions 2005. The result also shown that the hygiene conditions of household remain improved in both periods in 2005 and 2011, their morbidity members of all major states have shown lower than among the other states, whose household hygiene conditions remained in poor in both periods in 2005 and 2011.

The household who were lived in poor hygiene conditions in both periods 2005 and 2011, their average members of household fall sick due to ASM is higher among following the top states are Uttaranchal 45.7\% Chhattisgarh 30.2\% (Punjab, Himachal Pradesh 29\%), (Bihar, Uttar Pradesh 28) and Madhya Pradesh 23.6\% respectively. The socioeconomically poorer states such as Madhya Pradesh, Bihar, Uttar Pradesh and Chhattisgarh have shown higher morbidity is due to poor hygiene condition because of poor accessibility of water, sanitation and hygiene facilities and less consciousness of their hygiene practices. ${ }^{40}$ The economically better -off state Punjab has shown higher morbidity due higher utilization of health care services. ${ }^{40}$ On the other hand, the households who have been turned down into worse-off hygienic condition in 2011 from better -off hygienic condition in 2005, their average morbidity of household members following the highest state are Uttar Pradesh 33.1\%, Chhattisgarh 30.3\%, Punjab 29.6\%, Andhra Pradesh 
Table 4

Average percentage members of households fall in sick due to short term morbidity according to change in their household hygienic behavior in India and its states.

\begin{tabular}{|c|c|c|c|c|}
\hline \multirow[t]{2}{*}{ States } & \multicolumn{4}{|c|}{$\begin{array}{l}\text { Average percentage of household members with short term } \\
\text { morbidity by change of the household hygienic behavior }\end{array}$} \\
\hline & $\begin{array}{l}\text { Poor in } \\
2005 \\
2011\end{array}$ & $\begin{array}{l}\text { Poor in } 2005 \\
\text { but Not poor in } \\
2011\end{array}$ & $\begin{array}{l}\text { Non-poor in } \\
2005 \text { but Poor } \\
\text { in } 2011\end{array}$ & $\begin{array}{l}\text { Not poor in } \\
2005 \& \\
2011\end{array}$ \\
\hline $\begin{array}{l}\text { Jammu \& } \\
\text { Kashmir }\end{array}$ & 10.6 & 7.8 & 17.5 & 13.4 \\
\hline $\begin{array}{r}\text { Himachal } \\
\text { Pradesh }\end{array}$ & 29.0 & 22.0 & 18.6 & 18.9 \\
\hline Punjab & 29.0 & 19.0 & 29.6 & 21.2 \\
\hline Uttaranchal & 45.7 & 20.1 & 18.7 & 27.7 \\
\hline Haryana & 17.6 & 12.9 & 17.3 & 13.6 \\
\hline Delhi & 0.0 & 13.3 & 16.8 & 10.9 \\
\hline Rajasthan & 16.4 & 15.8 & 17.3 & 14.8 \\
\hline Uttar Pradesh & 28.0 & 30.8 & 33.1 & 27.2 \\
\hline Bihar & 28.4 & 16.1 & 21.6 & 18.4 \\
\hline Tripura & 7.0 & 7.7 & 13.3 & 8.6 \\
\hline Assam & 11.8 & 12.1 & 21.1 & 13.4 \\
\hline West Bengal & 21.0 & 21.2 & 21.4 & 19.2 \\
\hline Jharkhand & 12.6 & 9.9 & 11.7 & 12.1 \\
\hline Odisha & 11.8 & 12.6 & 10.3 & 13.7 \\
\hline Chhattisgarh & 30.2 & 32.2 & 30.3 & 25.4 \\
\hline $\begin{array}{l}\text { Madhya } \\
\text { Pradesh }\end{array}$ & 23.6 & 19.5 & 23.7 & 19.1 \\
\hline Gujarat & 19.5 & 9.8 & 14.2 & 10.0 \\
\hline Maharashtra & 13.5 & 13.2 & 14.9 & 10.5 \\
\hline $\begin{array}{l}\text { Andhra } \\
\text { Pradesh }\end{array}$ & 23.1 & 19.2 & 26.0 & 16.3 \\
\hline Karnataka & 11.8 & 11.3 & 13.7 & 11.3 \\
\hline Kerala & 10.0 & 11.9 & 15.7 & 14.8 \\
\hline Tamil Nadu & 14.5 & 9.8 & 5.0 & 8.8 \\
\hline Pondicherry & 2.2 & 4.9 & 0.0 & 2.2 \\
\hline Total & 21.3 & 17.4 & 19.0 & 16.0 \\
\hline
\end{tabular}

$26 \%$ and Bihar 21.6\%.

\subsection{The impact of change in household hygiene conditions on ASM}

Table 5 shows the transition in the percentage of household members fall sick due to ASM in response to the change in household hygiene conditions. The prevalence of ASM is remained low in the households either have better-off in hygiene conditions in both years in 2005 and 2011 (3\%) or became better-off in hygiene conditions in the recent year

Table 5

Transition in percentage of any short term morbidity for household members by change in household hygienic behavior.

\begin{tabular}{|c|c|c|c|c|c|}
\hline \multirow[b]{2}{*}{$\begin{array}{l}\text { Change in } \\
\text { hygienic } \\
\text { behavior of } \\
\text { household } \\
\text { members }\end{array}$} & \multicolumn{5}{|c|}{ Change in any short term morbidity } \\
\hline & $\begin{array}{l}\text { Not sick in } \\
2005 \& 2011\end{array}$ & $\begin{array}{l}\text { Not sick } \\
\text { in } \\
2005 \& \\
\text { sick in } \\
2011\end{array}$ & $\begin{array}{l}\text { Sick in } \\
2005 \& \\
\text { not sick } \\
\text { in } 2011\end{array}$ & $\begin{array}{l}\text { Sick in } \\
2005 \& 2011\end{array}$ & $\mathrm{n}$ \\
\hline $\begin{array}{c}\text { Poor in } 2005 \\
\text { and } 2011\end{array}$ & 66.6 & 16.3 & 11.8 & 5.4 & 7772 \\
\hline $\begin{array}{l}\text { Poor in } 2005 \\
\text { and non- } \\
\text { poor in } \\
2011\end{array}$ & 72.5 & 14.6 & 9.6 & 3.4 & 7161 \\
\hline $\begin{array}{l}\text { Non- poor in } \\
2005 \text { and } \\
\text { poor in } \\
2011\end{array}$ & 71.6 & 16.3 & 10.5 & 3.6 & 4132 \\
\hline $\begin{array}{l}\text { Non-poor } \\
\text { in } 2005 \text { and } \\
2011\end{array}$ & 74.4 & 13.3 & 9.4 & 3.0 & 15,066 \\
\hline Total & 71.4 & 14.7 & 10.3 & 3.9 & 34,131 \\
\hline \multicolumn{6}{|c|}{ Pearson chi2 $(9)=135.4120, \operatorname{Pr}<0.000$} \\
\hline
\end{tabular}

in 2011 (3.4\%) as compared to their counterparts who were remained in a poor hygienic condition either in both years in 2005 and 2011 (5.4\%) or became worse-off in hygiene conditions in the recent year in 2011 (3.6). Whereas the percentage of the household members who were not sick in 2005 and fell in sick in 2011 is lowered in the households either have better-off hygiene conditions in both years in 2005 and 2011 (13.3\%) or became better -off in the recent year in 2011 (14.6\%) compare to their counterparts households who were remained in poor hygiene conditions either in both years in 2005 and 2011 (16.3\%) or lived in poor hygiene conditions in the recent year in 2011 (16.3\%). The chi-squire statics has shown significant association between the transition of the household hygiene conditions and the transition in ASM (Pearson chi2 value $=135.4120, \operatorname{Pr}<0.0001$ ).

Fig. 1 shows the percentage of members of household falls sick due to any short-term morbidity is continuous linear variable and normally distributed hence we can apply multivariate linear regression.

Table 6 represent association between household members fall sick due to ASM and change in hygiene conditions of household with controlling various socioeconomic factors. The results from multivariate linear regression shows that the percentage members of households fall sick due to ASM is significantly higher $(\beta=0.053, \mathrm{P}<0.001)$ among the households who were continuously lived in poor hygiene conditions in both years in 2005 and 2011 as compared to the households who were remain lived in better-off hygiene conditions in both years in 2005 and 2011 after controlling socio-economic characteristics of the households. The percentage members of household fall sick due to ASM has significantly declined ( $\beta=-0.028, \mathrm{P}<0.04)$ among the households who were lived in the poor hygienic condition in 2005 but they turned into better off conditions as a compared to other households who were lived in the better-off hygienic condition in both years in 2005 and 2011. In religion categories of households, the percentage of morbidity members of Muslim households fall in sick in ASM has declined $(\beta=-0.107, \mathrm{P}<$ 0.001 ) as compared to Hindu households. In regional categories of households, the percentage morbidity members of Central $(\beta=0.154, \mathrm{P}$ $<0.001)$ followed by Eastern $(\beta=0.053, \mathrm{P}<0.001)$ and Southern households $(\beta=0.117, \mathrm{P}<0.001)$ has increased as a compared to Northern household. Whereas, the percentage morbidity members of western region households $(\beta=-0.052, \mathrm{P}<0.01)$ has declined as compared to Northern households.

Table 7 shows that the impact of change in household hygiene conditions and demographic and socio-economic factors on likelihood reporting of the change in ASM by fitting the multinomial logistic regression model. The adjusted percentages of household members fall

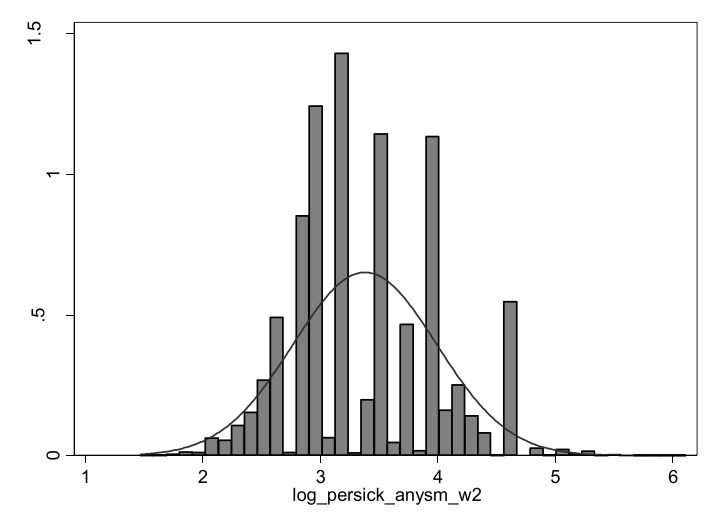

Note: Log_persick_anysm stand for Log of the percentage of household members falling sick due to any shortterm morbidity.

Fig. 1. Normal probability curve of the percentage of household members falling sick due to any short-term morbidity.

Note: Log_persick_anysm stand for Log of the percentage of household members falling sick due to any short-term morbidity. 
Table 6

Multivariate linear regression estimates: Probability of falling in sick due to any short term morbidity by the change in household Hygienic behavior and socioeconomic characteristics of the households.

\begin{tabular}{|c|c|c|c|c|}
\hline $\begin{array}{l}\text { Change in Household Hygiene } \\
\text { Non-poor in } 2005 \text { and } 2011 \circledR\end{array}$ & $\begin{array}{l}(\beta \\
\text { coefficient) }\end{array}$ & $\begin{array}{l}\mathrm{P} \text { - } \\
\text { value }\end{array}$ & \multicolumn{2}{|c|}{$95 \% \mathrm{CI}$ of $\beta$} \\
\hline Poor in 2005 and 2011 & 0.053 & 0.00 & 0.025 & 0.081 \\
\hline $\begin{array}{l}\text { Poor in } 2005 \text { and non-poor in } \\
2011\end{array}$ & -0.028 & 0.04 & -0.055 & -0.0008 \\
\hline $\begin{array}{l}\text { Non poor in } 2005 \text { and poor in } \\
2011\end{array}$ & 0.005 & 0.78 & -0.028 & 0.0368 \\
\hline \multicolumn{5}{|l|}{ Place of residence } \\
\hline \multicolumn{5}{|l|}{ Rural $(\mathbb{R}$} \\
\hline Urban & -0.021 & 0.10 & -0.047 & 0.0042 \\
\hline \multicolumn{5}{|l|}{ Type of house } \\
\hline \multicolumn{5}{|l|}{ Kucha ${ }^{\circledR}$} \\
\hline Pucca & -0.024 & 0.05 & -0.047 & -0.0004 \\
\hline \multicolumn{5}{|l|}{ Occupation } \\
\hline \multicolumn{5}{|l|}{ No-occupation ${ }^{\circledR}$} \\
\hline Primary & 0.002 & 0.91 & -0.033 & 0.0373 \\
\hline Secondary & 0.008 & 0.71 & -0.036 & 0.0531 \\
\hline Tertiary & 0.002 & 0.93 & -0.04 & 0.0437 \\
\hline \multicolumn{5}{|l|}{ Education } \\
\hline \multicolumn{5}{|l|}{ Illiterate ${ }^{\circledR}$} \\
\hline Primary & 0.004 & 0.80 & -0.027 & 0.0346 \\
\hline Secondary & 0.019 & 0.16 & -0.008 & 0.0463 \\
\hline Higher & 0.043 & 0.19 & -0.021 & 0.1056 \\
\hline \multicolumn{5}{|l|}{ Economic status } \\
\hline \multicolumn{5}{|l|}{ Poor ${ }^{\circledR}$} \\
\hline Non-poor & 0.084 & 0.00 & 0.0602 & 0.1077 \\
\hline \multicolumn{5}{|l|}{ Caste } \\
\hline \multicolumn{5}{|l|}{ General $\AA$} \\
\hline $\mathrm{OBC}$ & -0.011 & 0.37 & -0.035 & 0.0132 \\
\hline SC & -0.008 & 0.58 & -0.037 & 0.0206 \\
\hline ST & -0.072 & 0.00 & -0.114 & -0.0293 \\
\hline \multicolumn{5}{|l|}{ Religion } \\
\hline \multicolumn{5}{|l|}{ Hindu ${ }^{\circledR}$} \\
\hline Muslim & -0.107 & 0.00 & -0.138 & -0.0766 \\
\hline Christian & 0.036 & 0.08 & -0.004 & 0.0754 \\
\hline \multicolumn{5}{|l|}{ Region } \\
\hline \multicolumn{5}{|l|}{ North $®$} \\
\hline Central & 0.154 & 0.00 & 0.1247 & 0.1827 \\
\hline East & 0.053 & 0.00 & 0.0218 & 0.0846 \\
\hline Northeast & 0.021 & 0.53 & -0.044 & 0.0855 \\
\hline West & -0.052 & 0.01 & -0.088 & -0.0156 \\
\hline South & 0.117 & 0.00 & 0.0855 & 0.1478 \\
\hline Constant & 3.268527 & 0.00 & 3.2194 & 3.3176 \\
\hline Total number of observations & 15858 & & & \\
\hline R-squared & 0.0038 & & & \\
\hline Adjusted R-squared & 0.0036 & & & \\
\hline Prob $>F=0.0000$ & & & & \\
\hline
\end{tabular}

( Stands for Reference category. CI stands for Confidence Interval.

sick with the change in ASM by the change in household hygiene conditions and demographic and socio-economic factors are arranged. The significant differences are observed between changes in the percentage members of household fall sick due to ASM and change in household hygiene conditions. The members of households fall in sick with ASM was significantly remained low $(2.8 \%$; P $<0.01)$ in 2005 and 2011 among the households who were lived remain in better-off hygiene conditions in both years in 2005 and 2011 as compared to the households who were lived remain in poor hygiene conditions in 2005 and 2011 (4.8\%). The members of households fall in sick with ASM was remained low $(3.3 \%$; $\mathrm{P}<0.05)$ among the households whose hygienic condition has been turned into the better-off hygienic condition in 2011 from the poor hygienic condition in 2005 as compared to other households (3.5\%; $\mathrm{P}<0.05)$ whose hygienic condition has been turned down into poor hygienic condition in 2011 from the better-off hygienic condition in 2005. The members of households who were not sick in 2005 and fell in sick in 2011 was significantly low $(12.5 \%$; $\mathrm{P}<0.01)$ among the households who were lived remain in the better-off hygienic
Table 7

Multinomial logistic regression analysis: Adjusted percentage of change in any short term morbidity by change in household Hygienic behavior and socioeconomic variables.

\begin{tabular}{lllll}
\hline $\begin{array}{l}\text { Background } \\
\text { variables }\end{array}$ & No-sick in & No-sick in & Sick in & Sick in \\
& $2005 \& 2011$ & $\begin{array}{l}2005 \& \text { sick } \\
\text { in 2011 }\end{array}$ & $\begin{array}{l}\text { 2005\& no- } \\
\text { sick in 2011 }\end{array}$ & 2005\&2011 \\
\hline
\end{tabular}

\begin{tabular}{|c|c|c|c|c|}
\hline \multicolumn{5}{|l|}{$\begin{array}{l}\text { Change in } \\
\text { household } \\
\text { hygiene }\end{array}$} \\
\hline $\begin{array}{l}\text { Poor in } 2005 \\
2011 \circledR\end{array}$ & 67.6 & 16.1 & 11.6 & 4.8 \\
\hline $\begin{array}{l}\text { Poor in } 2005 \text { and } \\
\text { non-poor in } \\
2011\end{array}$ & 72.8 & 14.1 & $9.9 * *$ & $3.3^{* *}$ \\
\hline $\begin{array}{l}\text { Non-poor } 2005 \\
\text { and poor in } \\
2011\end{array}$ & 72.4 & 14.5 & $9.7^{* * *}$ & $3.5^{* *}$ \\
\hline $\begin{array}{l}\text { Non-poor in } 2005 \\
\text { and } 2011\end{array}$ & 75.3 & $12.5^{* * *}$ & $9.5^{* *}$ & $2.8^{* * * *}$ \\
\hline \multicolumn{5}{|l|}{$\begin{array}{l}\text { Place of } \\
\text { residence }\end{array}$} \\
\hline Rural $\mathbb{R}$ & 70.6 & 14.8 & 10.7 & 3.9 \\
\hline Urban & 76.8 & $12.0^{* *}$ & $8.7^{* *}$ & 2.6 \\
\hline \multicolumn{5}{|l|}{ Type of house } \\
\hline Kucha ${ }^{\circledR}$ & 70.0 & 15.0 & 11.0 & 4.1 \\
\hline Pucca & 76.7 & $12.4^{* *}$ & $8.5^{* * *}$ & $2.4^{* * *}$ \\
\hline \multicolumn{5}{|l|}{$\begin{array}{l}\text { Occupation } \\
\text { head of the } \\
\text { household }\end{array}$} \\
\hline $\operatorname{Primary}{ }^{\circledR}$ & 71.6 & 14.5 & 10.3 & 3.6 \\
\hline Secondary & 72.8 & 13.1 & 10.1 & $4.0 * *$ \\
\hline Tertiary & 74.6 & 13.3 & 9.3 & 2.8 \\
\hline No-Occupatiion & 70.8 & 13.8 & 11.0 & $4.3^{* *}$ \\
\hline \multicolumn{5}{|l|}{$\begin{array}{l}\text { Education head } \\
\text { of the } \\
\text { household }\end{array}$} \\
\hline Illiterate $®$ & 71.4 & 14.7 & 10.3 & 3.7 \\
\hline Primary & 72.6 & 13.7 & 10.4 & 3.3 \\
\hline Secondary & 73.6 & 13.1 & 10.1 & 3.2 \\
\hline Higher & 77.8 & $10.5^{* * *}$ & 8.3 & 3.4 \\
\hline \multicolumn{5}{|l|}{ Economic status } \\
\hline Poor ${ }^{\circledR}$ & 72.7 & 15.3 & 9.1 & 2.9 \\
\hline Non poor & 72.0 & 13.8 & $10.5^{* * *}$ & $3.7^{* * *}$ \\
\hline \multicolumn{5}{|l|}{ Social group } \\
\hline General $®$ & 73.5 & 13.5 & 9.9 & 3.2 \\
\hline OBC & 71.8 & 14.7 & 9.9 & 3.6 \\
\hline SC & 69.6 & 15.0 & $11.3^{* *}$ & 4.1 \\
\hline ST & 76.9 & $10.9^{* * * *}$ & 9.6 & 2.6 \\
\hline \multicolumn{5}{|l|}{ Religion } \\
\hline Hindu ${ }^{\circledR}$ & 72.0 & 14.2 & 10.3 & 3.6 \\
\hline Muslim & 71.3 & 14.8 & 10.1 & 3.8 \\
\hline Christian & 76.0 & 12.1 & 9.5 & 2.3 \\
\hline \multicolumn{5}{|l|}{ Region } \\
\hline $\operatorname{North}^{\circledR}$ & 74.2 & 13.7 & 9.2 & 2.9 \\
\hline Central & 62.5 & $21.0^{* * *}$ & $11.1^{* * *}$ & $5.4 * * *$ \\
\hline East & 68.1 & 13.6 & $13.3^{* * *}$ & $5.1^{* * *}$ \\
\hline Northeast & 80.3 & $10.5^{* * *}$ & $8.0^{* *}$ & $1.2^{* * *}$ \\
\hline West & 79.4 & $9.2^{* * *}$ & 9.3 & $2.1^{* * *}$ \\
\hline South & 77.9 & $12.4^{* * *}$ & $7.8^{* * *}$ & $1.9^{* * *}$ \\
\hline Total & 72.1 & 14.1 & 10.2 & 3.5 \\
\hline $\begin{array}{l}\text { Number of obs }= \\
34131\end{array}$ & Log li & -28081.1 & & \\
\hline \multicolumn{4}{|l|}{ LR chi2 $=$} & 1125.55 \\
\hline \multicolumn{5}{|l|}{$\begin{array}{l}\text { Prob }>\text { chi } 2= \\
0.0000\end{array}$} \\
\hline $\begin{array}{l}\text { Pseudo R2 = } \\
0.0196\end{array}$ & & & & \\
\hline
\end{tabular}

(B) Stands for Reference category. CI stands for Confidence Interval. $\mathrm{P}<0.1, \mathrm{P}<$ 0.05 and $\mathrm{P}<0.01$.

condition in 2005 and 2011 as compared to other households (16.1\%) who were living remain in poor hygiene conditions in both years in 2005 and 2011.

The percentage of members of households who were not sick in 2005 
and fell sick due to ASM in 2011 was low among the urban $(12 \%$; $\mathrm{P}<$ $0.05)$ households as compared to rural $(14.8 \%)$ households. Similarly, the percentage of members of households who were not sick in 2005 and fell in sick in 2011 was low among pucca $(12.4 \%$; $P<0.05)$ households as compared to Kucha households (15\%). The percentage of members of higher educated households who were not sick in 2005 and sick with ASM in 2011 have shown lower $(10.5 \%$; P < 0.01) morbidity as compared to illiterate members of households (14.7\%). The percentage of members of ST households who were not sick in 2005 and sick with ASM in 2011 have shown lower $(10.9 \%$; $\mathrm{P}<0.01)$ morbidity as compared to General caste members of households (13.5\%). The lower morbidity among the ST households is due to under-reporting. There are significant regional differences were observed in morbidity. The percentage of members of the central region $(21 \%$; $P<0.01)$ households who were not sick in 2005 and sick with ASM in 2011 have shown higher morbidity as compared to the Northern region of households (13.7\%). While the percentage members of Western $(9.2 \%)$ followed by Northeast (10.5\%; $\mathrm{P}<0.01)$ and Southern $(12.4 ; \mathrm{P}<0.01)$ region households who were not sick in 2005 and sick with ASM in 2011 have shown lower morbidity as compared to Northern region households (13.7\%). The morbidity members of pucca households $(2.4 \%$; $>0.01)$ have shown remained lower morbidity as compared to Kucha households (4.1\%). The central (4.4\%; $\mathrm{P}<0.01)$ and eastern region $(5.1 \%$ : $\mathrm{P}<0.01)$ have experienced remain higher morbidity as compared to northern households (2.9\%).

\section{Discussion}

This is the first study that has attempted to assess dynamic of change in morbidity members of households with respect to change in the household hygiene conditions and the impact of change in household hygiene conditions on morbidity members of the household by using longitudinal data. In this study, we found that any short term morbidity was significantly higher among the households who were continuously lived in the poor hygienic condition in both years in 2005 and 2011 as compared to other households who were remain lived in the better-off hygienic condition in both years in 2005 and 2011. The any shortterm morbidity has significantly declined among the households whose hygiene practices changed from poor in 2005 into better off condition in 2011.

Declined in the morbidity of household members as result of improvement of hygiene of household from poor hygiene in 2005 to better-off hygiene in 2011. During 2005-2011, there were government flagship programs such as National Rural Drinking Water Programme, Total Sanitation Programme and National Rural Health Mission were implemented to improve the improved source of drinking water, sanitation facilities, and hygiene practices which had made them better hygienic practices. However, all these flagships were made little progress in achieving the WASH facilities due to poor operational management. The household practices of poor hygiene remained over time from 2005 to 2012 is $29 \%$. The results have shown that the morbidity is higher among the households who were remained in the poor hygienic condition during both periods in 2004-05 and 2011-12. Our results indicate that as higher morbidity due to persistent poor hygiene practices over period of time is consistent with other cross-sectional studies such as poor hygiene practices as the use of an unimproved source of drinking water as not treatment of water, not washing hand with soap after defecating, not cleaning toilet properly, cooking unhygienic place and combustion of biomass for cooking all these factors leads to an increase in the risk of morbidities. ${ }^{26-34}$ The households living with better-off hygiene conditions are less likely fall in sick with any short term morbidities were consistent with other cross-sectional studies. For instance, an improved method of handwashing practices reduces the fall in sick with diarrhea morbidity.${ }^{16}$ Similarly, A number of the studies were found that a $32 \%$ reduction of diarrhea episodes among the children after community intervention of hygienic practices in developing countries. $^{6,6,7}$

After controlling other socio-economic factors, increase in morbidity among the household members who had not reported morbidity in 2005 and reported morbidity in 2011 is less likely among the educated household members compared to illiterate households. This finding is contradictory nature to the previous literature found that reporting of morbidity by higher educated households was higher than the illiterate households due to more utilization of health care facilities. ${ }^{35,36}$ However, the better educated household have better-off hygienic practices than the illiterate households which cause to lower morbidity. Therefore, increase in morbidity is less likely among the higher educated household.

\section{Conclusion and recommendations}

The prevalence of morbidity is found higher among the households from rural, Kucha, central and eastern region. It is might be due to poor hygiene practices. The household's use of improved sanitation facilities makes better hygiene practices. In rural areas, the households are not using the sanitation facilities due to poor quality in standard which were provided by governments. ${ }^{37}$ Based on the findings of this study we suggest that the ongoing programs such as 'Swatch Bharat Abhiyan' (Clean India Mission), Jal Jeevan Mission (Improved Source of Drinking Water Scheme) and 'Housing for All by 2020', which were launched in 2019, 2014 and 2016 respectively by the Government of India, need to concentrate in rural area and Centre and eastern region to provide water, high quality of sanitation facilities and good Pucca house which are prerequisite to adopting better hygiene practices. It also needs to create health awareness among these sections of the population to not fall in sick repeatedly. It was found that even though the availability of water and sanitation facilities unless people are knowledgeable on the health risk posed for not practicing proper hygiene, it is likely that they ignore or under practice hygiene. ${ }^{17}$ Therefore, Providing improved water supply and sanitation facilities alone do not lead to automatically adopt their hygiene practices ${ }^{2}$ and Proper hygiene cannot be ensured with the only provision of hygiene facilities. ${ }^{18}$ Even though hygiene facilities are available, the behavior of the users does matter to adopt hygiene practices in the effective control of those communicable diseases in India. ${ }^{40-43}$ Therefore, it is necessary to make change the behavior of the household members to maintain good health through better hygiene practices to prevent communicable and infectious disease through information and communication technology (social media) and educate the theme.

\section{Limitation of the study}

Any short term morbidity such as diarrhea, fever and cough is influenced by seasonal variation. The study has not included the effect of seasonal variation on morbidity due to non-availability of data in the survey.

\section{Availability of data and materials}

This study used secondary data source. The data is available in the public domain and can be accessed from this link https://www.icpsr. umich.edu/web/DSDR/studies/37382.

\section{Funding}

Authors recieved no funding for this research. This research paper is independent work of main author and my co-other from Ph.D. thesis

\section{Declaration of competing interest}

The authors declared no conflict and interest. 


\section{References}

1 World Health Organization. Hygiene: World Health Organization; 2013. Available from: http://www.who.int/topics/hygiene/en/.

2 Van Wijk C, Murre T. Motivating Better Hygiene Behaviour: Importance for Public Health Mechanisms of Change. IRC International Water and Sanitation Centre; 1999.

3 Semba RD, Kraemer K, Sun K, et al. Relationship of the presence of a household improved latrine with diarrhea and under-five child mortality in Indonesia. Am J Trop Med Hyg. 2011;84(3):443-450.

4 Simiyu S, Swilling M, Cairncross S, Rheingans R. Determinants of quality of shared sanitation facilities in informal settlements: case study of Kisumu, Kenya. BMC Publ Health. 2017;17(1):1-3.

5 United Nations. Report Of the Secretary General: Progress towards the Sustainable Development Goals: Progress of. 2017. Available online: https://sustainabledeve lopment.un.org/sdg3.

6 Ejemot-Nwadiaro RI, Ehiri JE, Meremikwu MM, Critchley JA. Hand washing for preventing diarrhoea. Cochrane Database Syst Rev. 2008;(1).

7 Fewtrell L, Kaufmann RB, Kay D, Enanoria W, Haller L, Colford Jr JM. Water, sanitation, and hygiene interventions to reduce diarrhoea in less developed countries: a systematic review and meta-analysis. Lancet Infect. 2005;5(1):42-52.

8 Waddington H, Snilstveit B. Effectiveness and sustainability of water, sanitation, and hygiene interventions in combating diarrhoea. J Dev Effect. 2009;1(3):295-335.

9 Cairncross S, Hunt C, Boisson S, et al. Water, sanitation and hygiene for the prevention of diarrhoea. Int J Epidemiol. 2010;39(suppl 1):i193-205.

10 Curtis V. Hygiene: how myths, monsters, and mothers-in-law can promote behaviour change. J Infect. 2001;43(1):75-79.

11 Boschi-Pinto C, Velebit L, Shibuya K. Estimating child mortality due to diarrhoea in developing countries. Bull World Health Organ. 2008;86:710-717.

12 WHO. Reducing Mortality from Major Childhood Killer Diseases: Mortality Country Fact Sheet; 2006, 180 https://apps.who.int/chd/publications/imci/fs_180.htm.

13 Vivas A, Gelaye B, Aboset N, Kumie A, Berhane Y, Williams MA. Knowledge, attitudes, and practices (KAP) of hygiene among school children in Angolela, Ethiopia. J Prev Med Hyg. 2010;51(2):73.

14 Nabavi M, Alavi-Moghaddam M, Gachkar L, Moeinian M. Knowledge, attitudes, and practices study on hand hygiene among Imam Hossein Hospital's residents in 2013. Iran Red Crescent Med J. 2015;17(10).

15 Nair SS, Hanumantappa R, Hiremath SG, Siraj MA, Raghunath P. Knowledge, attitude, and practice of hand hygiene among medical and nursing students at a tertiary health care centre in Raichur, India. Int Sch Res Notices. 2014;2014.

16 Rah JH, Cronin AA, Badgaiyan B, Aguayo VM, Coates S, Ahmed S. Household sanitation and personal hygiene practices are associated with child stunting in rural India: a cross-sectional analysis of surveys. BMJ open. 2015 1;5(2).

17 Sultana M, Mahumud RA, Sarker AR, Hossain SM. Hand hygiene knowledge and practice among university students: evidence from private universities of Bangladesh. Risk Manag Healthc Pol. 2016;9:13.

18 Wasonga J, Olang'o CO, Kioli F. Improving households knowledge and attitude on water, sanitation, and hygiene practices through school health programme in Nyakach, Kisumu County in Western Kenya. J Anthropol Res. 2014;2014.

19 Ranasinghe S, Ramesh S, Jacobsen KH. Hygiene and mental health among middle school students in India and 11 other countries. J Infect Public Heal. 2016;9(4): 429-435.

20 Assefa M, Kumie A. Assessment of factors influencing hygiene behaviour among school children in Mereb-Leke District, Northern Ethiopia: a cross-sectional study. BMC Publ Health. 2014;14(1):1000.

21 Deb S, Dutta S, Dasgupta A, Misra R. Relationship of personal hygiene with nutrition and morbidity profile: a study among primary school children in South Kolkata. Indian J Community Med. 2010;35(2):280.

22 Arasu S, Fathima FN, Raghu N, et al. Nutritional status, hygiene level, morbidity profile, and their effect on scholastic performance among school children in two subcenter areas of a PHC in Anekal Taluk, Karnataka, India. Indian J Community Med. 2019;44(2):125.

23 Desai S, Vanneman R India. Human Development Survey-II (IHDS-II), 2011-12. ICPSR36151-V2. Ann Arbor, MI: Inter-university Consortium for Political and Social Research [distributor; 2015:7-31.

24 Desai SB, Dubey A, Joshi BL, Sen M, Sharif A, Vanneman R. India Human Development Survey: Design and Data Quality. New Delhi: Oxford University Press; 2010.

25 Retherford RD, Choe MK. Statistical Models for Causal Analysis. John Wiley \& Sons; $2011,1$.

26 Arokiasamy P, Karthick K, Pradhan J. Environmental risk factors and prevalence of asthma, tuberculosis and jaundice in India. Int J Environ Health Res. 2007;1(2): $221-242$.

27 Baldi I, Tessier JF, Kauffmann F, Jacqmin-Gadda H, Nejjari C, Salamon R. Prevalence of asthma and mean levels of air pollution: results from the French PAARC survey. Pollution Atomospherique et Affections Respiratoires Chroniques. Eur Respir J. 1999; 14(1):132-138.

28 Bates DV. Observations on asthma. Environ Health Perspect. 1995;103(suppl 6): 243-247.

29 Castellsague J, Sunyer J, Saez M, Anto JM. Short-term association between air pollution and emergency room visits for asthma in Barcelona. Thorax. 1995 Oct 1;50 (10):1051-1056.

30 Adane M, Mengistie B, Mulat W, Medhin G, Kloos H. The most important recommended times of hand washing with soap and water in preventing the occurrence of acute diarrhea among children under five years of age in slums of Addis Ababa, Ethiopia. J Community Health. 2018;43(2):400-405.

31 Curtis V, Cairncross S. Effect of washing hands with soap on diarrhoea risk in the community: a systematic review. Lancet Infect Dis. 2003;3(5):275-281.

32 Langford R, Lunn P, Brick CP. Hand-washing, subclinical infections, and growth: a longitudinal evaluation of an intervention in Nepali slums. Am J Hum Biol. 2011;23 (5):621-629.

33 Luby SP, Halder AK, Huda T, Unicomb L, Johnston RB. The effect of handwashing at recommended times with water alone and with soap on child diarrhea in rural Bangladesh: an observational study. PLoS Med. 2011;8(6), e1001052.

34 Dey NC, Parvez M, Islam MR, Mistry SK, Levine DI. Effectiveness of a communitybased water, sanitation, and hygiene (WASH) intervention in reduction of diarrhoea among under-five children: evidence from a repeated cross-sectional study (2007-2015) in rural Bangladesh. Int J Hyg Environ Health. 2019;222(8):1098-1108.

35 Subramanian SV, Subramanyam MA, Selvaraj S, Kawachi I. Are self-reports of health and morbidities in developing countries misleading? Evidence from India. Soc Sci Med. 2009;68(2):260-265.

36 Srinivasan TN, Muraleedharan VR, Pratap B. Morbidity in India since 1944. Indian Econ Rev. 2017;52(1):3-5.

37 Coffey D, Spears D. Where India Goes: Abandoned Toilets, Stunted Development and the Costs of Caste. India: Harper Collins; 2017 Jul 10.

38 Rutstein SO, Johnson K. DHS Comparative Reports 6: The DHS Wealth Index. Calverton, MD: ORC Macro; 2004 Aug.

39 Vyas S, Kumaranayake L. Constructing socio-economic status indices: how to use principal components analysis. Health Pol Plann. 2006;21(6):459-468.

40 Brahmanandam N, Nagarajan R. Impact of change in household environment condition on morbidity in India: evidence from longitudinal data. PloS One. 2021;16 (3), e0247465.

41 Coffey D, Spears D, Vyas S. Switching to sanitation: understanding latrine adoption in a representative panel of rural Indian households. Soc Sci Med. 2017;188:41-50.

42 Coffey D, Gupta A, Hathi P, et al. Revealed preference for open defecation. Econ Polit Wkly. 2014;49(38):43.

43 Gupta A, Khalid N, Desphande D, et al. Changes in Open Defecation in Rural North India: 2014-2018. 2019. IZA Discussion Paper No. 12065. 